\title{
Melt Protection of Mg-Al Based Alloys
}

\author{
María J. Balart *, Jayesh B. Patel * and Zhongyun Fan \\ BCAST, Brunel University, Uxbridge, Middlesex, UB8 3PH, UK; zhongyun.fan@brunel.ac.uk \\ * Correspondence: maria.balart@brunel.ac.uk (M.J.B.); jayesh.patel@brunel.ac.uk (J.B.P.); \\ Tel.: +44-1895-267105 (M.J.B. \& J.B.P.); Fax: +44-1895-269758 (M.J.B. \& J.B.P.)
}

Academic Editor: Hugo Lopez

Received: 23 March 2016; Accepted: 23 May 2016; Published: 30 May 2016

\begin{abstract}
This paper reports the current status of Mg melt protection in view to identify near-future challenges, but also opportunities, for $\mathrm{Mg}$ melt protection of $\mathrm{Mg}$ - $\mathrm{Al}$ based alloys. The goal is to design and manufacture sustainable $\mathrm{Mg}$ alloys for resource efficiency, recycling and minimising waste. Among alternative cover gas technologies for $\mathrm{Mg}$ melt protection other than $\mathrm{SF}_{6}$ : commercially available technologies containing-HFC-134a, fluorinated ketone and dilute $\mathrm{SO}_{2}$ - and developed technologies containing solid $\mathrm{CO}_{2}, \mathrm{BF}_{3}$ and $\mathrm{SO}_{2} \mathrm{~F}_{2}$, can potentially produce toxic and/or corrosive by-products. On the other hand, additions of alkaline earth metal oxides to $\mathrm{Mg}$ and its alloys have developed a strong comparative advantage in the field of $\mathrm{Mg}$ melt protection. The near-future challenges and opportunities for $\mathrm{Mg}$ - $\mathrm{Al}$ based alloys include optimising and using $\mathrm{CO}_{2}$ gas as feedstock for both melt protection and grain refinement and $\mathrm{TiO}_{2}$ additions for melt protection.
\end{abstract}

Keywords: magnesium alloys; oxidation; high temperature; liquid state; reactive element effect; $\mathrm{CO}_{2}$ gas

\section{Introduction}

The design and manufacturer [1] of sustainable Mg alloys and the need to reduce environmental impacts are the main factors that advance the development of new processes such as the replacement of $\mathrm{SF}_{6}$ gas [2-5]; and industrial furnace design, including lid design, addressing energy efficiency and metal losses in new and existing furnaces. In comparison to structural materials such as $\mathrm{Al}$ and steel, $\mathrm{Mg}$ components for automotive applications have better greenhouse gas emission performance (GHGEP) based on regular lifecycle assessments. However, this GHGEP advantage of Mg components can be significantly reduced depending on the production technology adopted, i.e., electrolytic versus thermal process, in both cases assuming replacement of $\mathrm{SF}_{6}$ cover gas [6].

Since $\mathrm{SF}_{6}$ has been identified as a GHG $[5,7,8]$, the protective films formed on molten magnesium and its alloys under gas protection have been an active subject of research, with the aim of finding suitable industrial alternatives to $\mathrm{SF}_{6}$ gas for melt protection [7-21]. The use of $\mathrm{SF}_{6}$ gas will be banned from the European Union from 2018 [22] (as cited in Reference [23]), in which case, replacement of $\mathrm{SF}_{6}$ as a cover gas in the $\mathrm{Mg}$ industry would no longer be eligible as Clean Development Mechanism (CDM) project or Joint Implementation (JI) project, nor sell the reduced emission as 'carbon credits' [24]. The International Magnesium Association (IMA) has recognised the need to identify melt protection alternatives with both low toxicity and GHG emissions $[25,26]$. In this paper, taking as a starting point a brief overview of the work on $\mathrm{Mg}$ melt protection, the near-future challenges, but also opportunities, for melt protection of $\mathrm{Mg}$-Al based alloys are identified.

\section{Reactive Element Effect}

It has been seventy-nine years since the 'rare earth element effect' was first proposed [27]. The original premise was that it was possible to obtain $\mathrm{Ni}-20 \mathrm{Cr}$ alloys in order to improve resistance to 
high temperature oxidation by additions of rare earth elements. A few years later the original concept of rare earth element effect was adapted and extended to other elements with high affinity to oxygen, to increase the corrosion resistance of refractory alloys without impairing their creep resistance. At this time, the 'active elements' suggested by Pfeil's patent were Sc, Y, La, Ti, Zr, Hf, Nb, Ta, Al, Si, Ce, Pr, $\mathrm{Nd}, \mathrm{Pm}, \mathrm{Sm}, \mathrm{Eu}, \mathrm{Gd}, \mathrm{Tb}, \mathrm{Dy}, \mathrm{Ho}, \mathrm{Er}, \mathrm{Tm}, \mathrm{Yb}, \mathrm{Lu}$ and Th [28] (as cited in Reference [29]). The topic became more commonly known as the 'Reactive Element Effect' (REE). A detailed review of the REE on high temperature oxidation of $\mathrm{Mg}$ was recently published by Czerwinski [27], including $\mathrm{Ca}, \mathrm{Be}, \mathrm{Sr}$ and $\mathrm{Ti}$, which readily oxidise when exposed to oxygen, give the magnesium alloy improved resistance to oxidation during melting. The high affinity to oxygen of those and all other rare earth elements are the basis of the REE [30-32]. Some examples of $\mathrm{Ca}, \mathrm{Be}, \mathrm{Sr}$ and $\mathrm{Ti}$ additions to molten $\mathrm{Mg}$ are given below. An Ellingham diagram [33,34] for their oxides including $\mathrm{Al}$ and $\mathrm{Mg}$ oxides is depicted in Figure 1, from which it can be seen that their affinity to oxygen until $1000 \mathrm{~K}\left(726.85^{\circ} \mathrm{C}\right)$ decreases in the following order $\mathrm{Ca}>\mathrm{Be}>\mathrm{Mg}>\mathrm{Sr}>\mathrm{Al}>\mathrm{Ti}$.

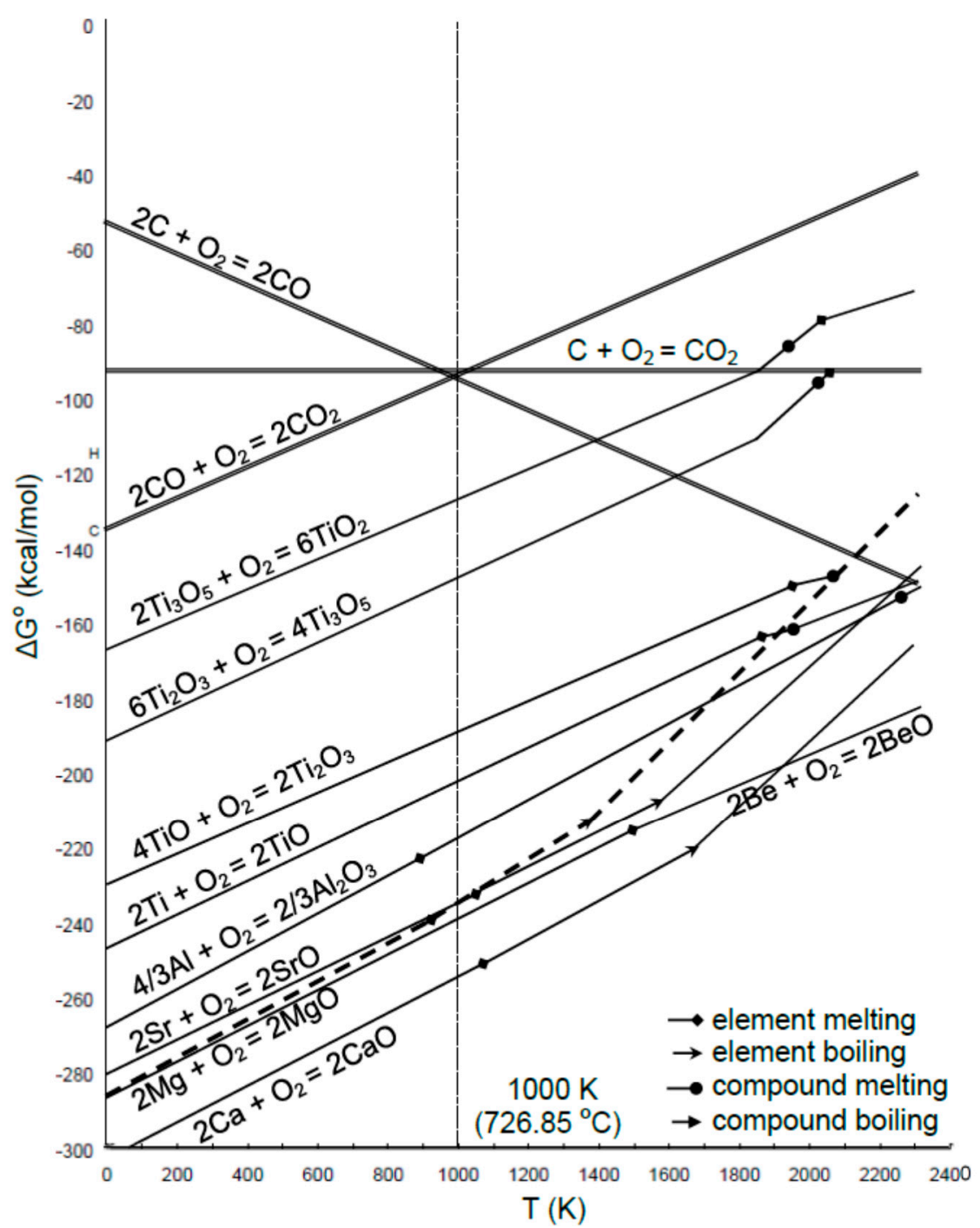

Figure 1. Schematic of the Ellingham diagram for selected oxides [33,34]. Mg oxidation is marked with a dashed line. Adapted from [34], copyright (2006), reprinted with permission of Stanley M. Howard.

\subsection{Ca Additions}

Sakamoto et al. [35] reported that the thin oxide layer formed on the surface of molten $\mathrm{Mg}-1.5 \mathrm{Ca}$ alloy was protective and consisted of an outer layer of $\mathrm{CaO}$ and an inner layer composed of a mixture 
of $\mathrm{CaO}$ and $\mathrm{MgO}$. In a subsequent study by Wiese et al. [23] at higher additions of $\mathrm{Ca}$, it was found that the thin oxide layer formed on the surface of molten $\mathrm{Mg}-7.2 \% \mathrm{CaO}$ alloy was also protective after exposure at $720{ }^{\circ} \mathrm{C}$ for $5 \mathrm{~min}$ in both air and $\mathrm{SF}_{6} / \mathrm{Ar}$ and by using SEM and TEM techniques, identified the formation of $\mathrm{Mg} / \mathrm{Mg}_{2} \mathrm{Ca}$ eutectic phase at the inner surface layer and of a mixture of $\mathrm{MgO} / \mathrm{CaO}$ at the outer surface layer, but also $\mathrm{Mg} / \mathrm{Mg}_{2} \mathrm{Ca}$ eutectic phase at the outer surface layer, suggesting that $\mathrm{Mg}_{2} \mathrm{Ca}$ phase was protective. It is interesting to note that $\mathrm{Mg}_{2} \mathrm{~F}$ was not found at the surface layer despite using an $\mathrm{SF}_{6} / \mathrm{Ar}$ gas mixture in the latter case. This was attributed to be due to the possible protective character of the $\mathrm{MgO} / \mathrm{CaO}$ mixture, preventing the reaction of $\mathrm{SF}_{6}$ gas at the surface of the Mg melt.

In practice, additions of $\mathrm{CaO}$ to $\mathrm{Mg}$ and $\mathrm{Mg}$-Al based alloys can lead to the formation of $\mathrm{Mg}_{2} \mathrm{Ca}$ according to reactions (1) and (2), respectively [4]. Note the solubility of Ca in liquid Mg. According to the $\mathrm{Mg}$-rich region of the equilibrium phase diagram of eutectic type for the $\mathrm{Mg}-\mathrm{Ca}$ system [36], the invariant point is 10.5 at. $\% \mathrm{Ca}$ at $516.5^{\circ} \mathrm{C}$. Therefore, the presence of $\mathrm{Mg}_{2} \mathrm{Ca}$ phase is to be expected for example at $700{ }^{\circ} \mathrm{C}$ in high Ca-containing $\mathrm{Mg}$ alloys only.

$$
\begin{gathered}
10 \mathrm{Mg}_{(\mathrm{l})}+4 \mathrm{CaO}_{(\mathrm{s})}=4 \mathrm{Mg}_{2} \mathrm{Ca}_{(\mathrm{s})}+\left[\mathrm{O}_{2}+2 \mathrm{MgO} \text { (dross) }\right] \\
\mathrm{Mg}[\mathrm{Al} \text {, other alloying elements }]_{(\mathrm{l})}+\mathrm{CaO}_{(\mathrm{s})}=\mathrm{Mg}_{2} \mathrm{Ca}_{(\mathrm{s})}+\mathrm{Al}_{2} \mathrm{Ca}_{(\mathrm{s})}+ \\
{\left[(\mathrm{Mg}, \mathrm{Al} \text {, other alloying elements })_{2} \mathrm{Ca}_{(\mathrm{s})}\right]+\left[\mathrm{O}_{2}+\mathrm{MgO} \text { (dross) }\right]}
\end{gathered}
$$

Indeed, recent work by Wiese et al. [37,38] confirms the reaction of $\mathrm{CaO}$ and the formation of $\mathrm{Mg}_{2} \mathrm{Ca}$ laves phase in the bulk of $\mathrm{Mg}-16 \mathrm{Ca}+6 \mathrm{CaO}$ and $\mathrm{Mg}-10 \mathrm{CaO}$ (in wt.\%) by in situ synchrotron measurements of the reaction between molten $\mathrm{Mg}$ and $\mathrm{CaO} . \mathrm{Mg}_{2} \mathrm{Ca}$ and $\mathrm{Al}_{2} \mathrm{Ca}$ are Laves phases with crystal structures and melting points of: hexagonal, $714{ }^{\circ} \mathrm{C}\left(\mathrm{Mg}_{2} \mathrm{Ca}\right)$ and cubic, $1079{ }^{\circ} \mathrm{C}\left(\mathrm{Al}_{2} \mathrm{Ca}\right)$, respectively [39]. The additions of alkaline earth metal oxides to $\mathrm{Mg}$ and its alloys have developed a strong comparative advantage in the field of $\mathrm{Mg}$ melt protection.

\subsection{Be Additions}

Be has a higher affinity to oxygen than $\mathrm{Mg}$. Trace additions of beryllium in the range between 5 and 30 ppm are made to Mg alloys [40], in particular AZ91D, AM60, AM50 and AZ31 Mg alloys may contain 5-10 ppm Be [27].

\subsection{Sr Additions}

Rare or alkaline earth metals additions are commonly made to $\mathrm{Mg}-\mathrm{Al}$ based alloys for creep-resistance applications, e.g., $\mathrm{Mg}$-Al-RE and $\mathrm{Mg}$-Al-Sr alloys [41]. The presence of $\mathrm{SrO} / \mathrm{MgO}$ in AJ62 alloy would be initially expected according to reaction (3) [42]. Note the solubility of Sr in liquid $\mathrm{Mg}$. At high concentrations of $\mathrm{Sr}$, it could react with molten $\mathrm{Mg}$ to form intermetallics such as $\mathrm{Mg}_{17} \mathrm{Sr}_{2}$, $\mathrm{Mg}_{38} \mathrm{Sr}_{9}, \mathrm{Mg}_{23} \mathrm{Sr}_{6}$ and $\mathrm{Mg}_{2} \mathrm{Sr}$ phases [43], but also SrO could react according to reaction (4) [4].

$$
2 \mathrm{Mg}_{(\mathrm{l})}+2 \mathrm{Sr}_{(\mathrm{l})}+4 / 3 \mathrm{Al}_{2} \mathrm{O}_{3(\mathrm{~s})}=2 \mathrm{MgO}_{(\mathrm{s})}+2 \mathrm{SrO}_{(\mathrm{s})}+8 / 3 \mathrm{Al}
$$

at $690^{\circ} \mathrm{C}, \Delta \mathrm{G}_{3}^{\circ}=-947,620 \mathrm{~J} / \mathrm{mol}$.

$\mathrm{Mg}[\mathrm{Al} \text {, other alloying elements }]_{(\mathrm{l})}+\mathrm{SrO}_{(\mathrm{s})}=\mathrm{Mg}_{2} \mathrm{Sr}_{(\mathrm{s})}+\mathrm{Al}_{2} \mathrm{Sr}_{(\mathrm{s})}+$

$\left[\left(\mathrm{Mg}, \mathrm{Al}\right.\right.$, other alloying elements $\left.{ }_{2} \mathrm{Sr}_{(\mathrm{s})}\right]+\left[\mathrm{O}_{2}+\mathrm{MgO}\right.$ (dross) $]$

From previous studies [42,44], Sr-bearing AJ62 alloy held at 690 for 10 s exhibited higher resistance to oxidation than that of Sr-free AZ91D alloy held at 650 for $10 \mathrm{~s}$, as shown from macroscopic observations of the reaction products formed on the surface in Figure 2, from which it can be seen two distinctive regions of non-nodular growth (in a layer manner) and of nodular growth, indicating two different stages of the surface reaction. Samples from these regions are outlined by the white squares marked 1-non-nodular growth-and 2-nodular growth-in Figure 2. FEG-SEM revealed that all the 
morphologies, i.e., sponge-like, nodular and layer, were porous and hence non-protective with respect to the evaporation and oxidation of $\mathrm{Mg}, \mathrm{Zn}$ and $\mathrm{Sr}$ from the corresponding surface of the AZ91D and AJ62 alloy melt, as shown in Figure 3. XRD results from the surface of AZ91D, AZ31, AM60 and AJ61 alloys indicated that, in all these regions, $\mathrm{MgO}$ was the main oxidation product along with traces of AlN. Additionally, traces of $\mathrm{ZnO}$ reflected the $\mathrm{Zn}$ levels of the $\mathrm{Mg}$ magnesium alloys and the oxidation conditions investigated.
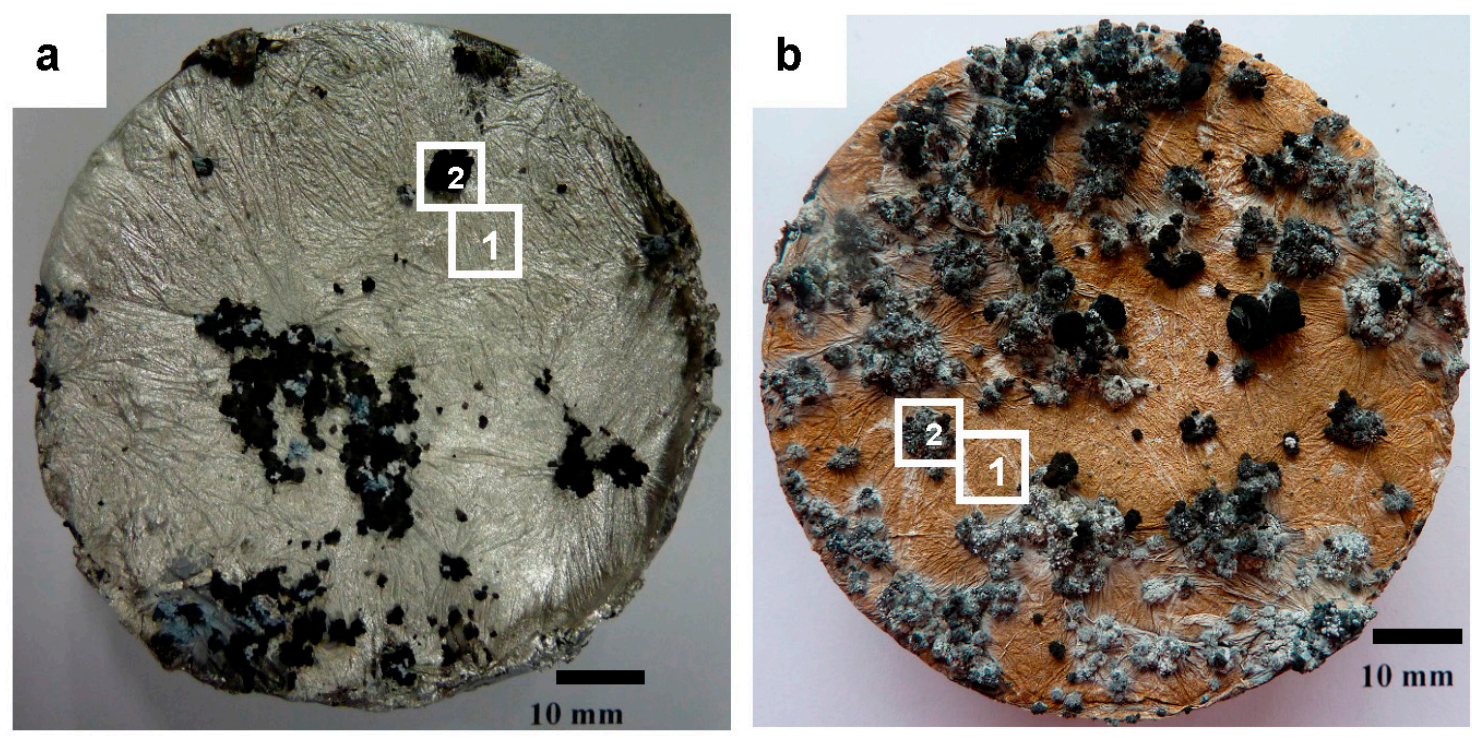

Figure 2. Macroscopic view of surface of Mg alloys exposed to air under two oxidation conditions: (a) AJ62 alloy held at $690^{\circ} \mathrm{C}$ for $10 \mathrm{~s}$, reprinted with permission from Reference [42], copyright 2014, Taylor \& Francis Ltd., www.tandfonline.com; (b) AZ91D alloy held at $650{ }^{\circ} \mathrm{C}$ for $10 \mathrm{~s}$, reprinted with permission from Reference [44], copyright 2014, Taylor \& Francis Ltd., www.tandfonline.com. Marked regions indicate following reaction stages: (1) non-nodular growth in layer manner and (2) nodular growth. AJ62 alloy exhibited higher resistance to high temperature oxidation than that of AZ91D alloy.
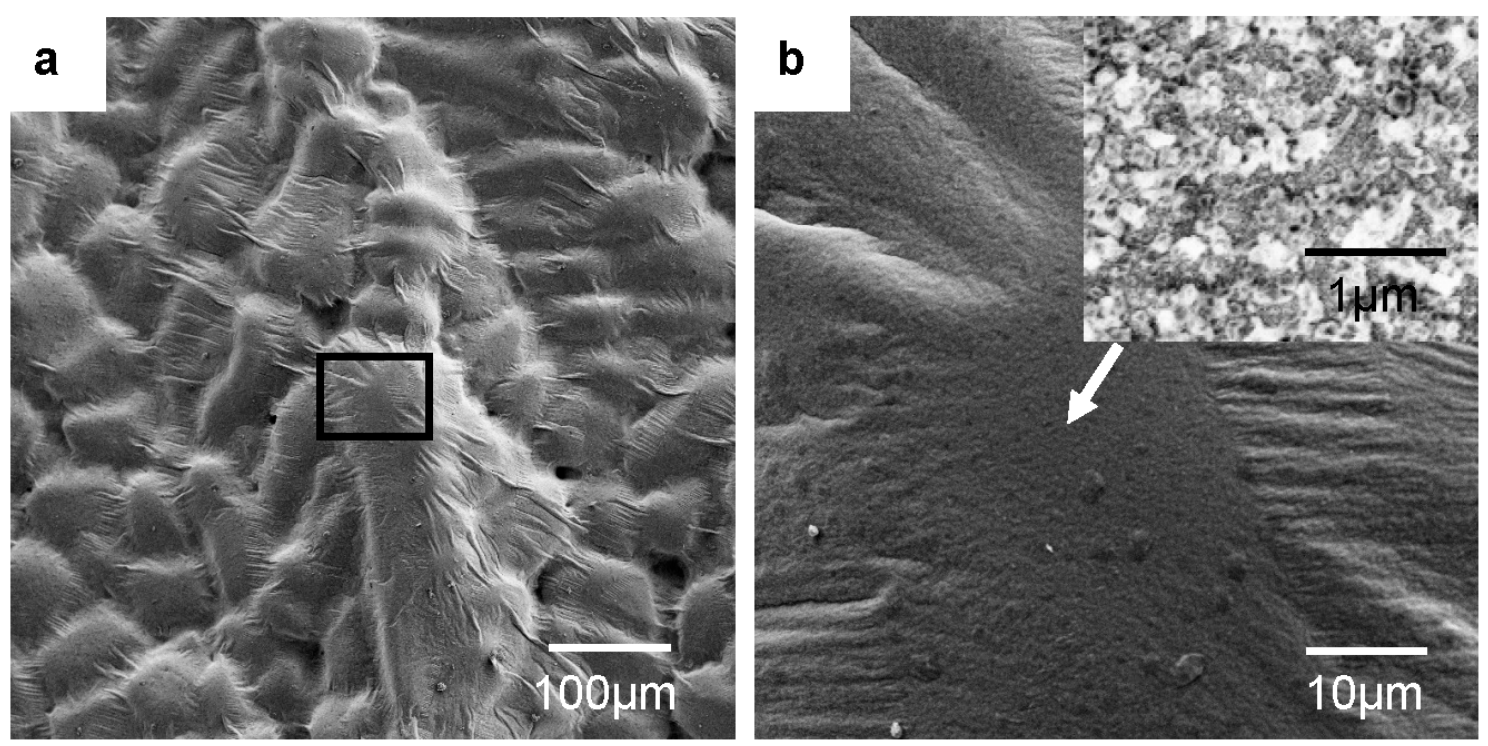

Figure 3. Secondary electron images from region marked 1 (macroscopic non-nodular growth) in Figure 2b, from surface of AZ91D alloy held at $650{ }^{\circ} \mathrm{C}$ for $10 \mathrm{~s}$ [44] showing (a) oxide layer; (b) magnification of region outlined by black rectangle in (a); detail of predominantly granular $\mathrm{MgO}$ nanoparticles (inset). 


\subsection{Ti Additions}

Some notable successes in $\mathrm{Mg}$ and $\mathrm{Mg}-9 \mathrm{Al}$ alloy have been an increase of over 30\% in strength and elongation with the introduction of $\mathrm{O}$ interstitial atoms, 50\% increase in formability, double creep resistance and a 10-fold increase in corrosion resistance [45].

First $\mathrm{TiO}_{2}$ nano-particles having high chemical potential energy are introduced into the $\mathrm{Mg}$ melt, and then they decompose to $\mathrm{O}, \mathrm{Ti}$ and $\mathrm{TiO}$. Subsequently, $\mathrm{Ti}$ and $\mathrm{TiO}$ having high specific gravity sink down to the bottom of the crucible. Finally, oxygen atoms in the $\mathrm{Mg}$ melt will remain interstitial after solidification. This was due to an increase in the activation energy for the formation of $\mathrm{MgO}$.

$\mathrm{Ti}$ has been found to inhibit $\mathrm{Mg}$ corrosion in aqueous solutions [27], and might also impact greatly on the field of high temperature oxidation of $\mathrm{Mg}$ alloys. $\mathrm{TiO}_{2}$ particles could react at the surface of Mg-Al based alloys. Thermodynamic analysis in conjunction with experimental evidence showed that the formation of $\mathrm{TiAl}$ can be favoured at the expense of other $\mathrm{Ti}_{\mathrm{x}} \mathrm{Al}_{\mathrm{y}}$ compounds [46]. This is because $\mathrm{Mg}$ has a higher affinity to oxygen than $\mathrm{Ti}$ and $\mathrm{Ti}$ reacts preferentially with $\mathrm{Al}$ to form $\mathrm{TiAl}$ (reaction (7)). TiAl has a high oxidation limit of $900{ }^{\circ} \mathrm{C}$ and a low density of $4.1-4.7 \mathrm{gr} / \mathrm{cm}^{3}[46,47]$. In contrast, the oxidation resistance of $\mathrm{Al}_{3} \mathrm{Ti}$ is much better than those of $\mathrm{TiAl}$ and $\mathrm{Ti}_{3} \mathrm{Al}$ [47].

$$
3 \mathrm{TiO}_{2(\mathrm{~s})}+7 \mathrm{Al}_{(\mathrm{l})}=2 \mathrm{Al}_{2} \mathrm{O}_{3(\mathrm{~s})}+3 \mathrm{TiAl}
$$

at $700{ }^{\circ} \mathrm{C}, \Delta \mathrm{G}^{\circ}{ }_{5}=-648,733 \mathrm{~J} / \mathrm{mol}[46]$

$$
3 \mathrm{Mg}_{(\mathrm{l})}+\mathrm{Al}_{2} \mathrm{O}_{3(\mathrm{~s})}=3 \mathrm{MgO}_{(\mathrm{s})}+2 \mathrm{Al}_{(\mathrm{l})}
$$

$\Delta \mathrm{G}^{\circ}{ }_{6}=-145,810+26.32 \mathrm{~T}[48]$, where $\Delta \mathrm{G}^{\circ}$ is in $\mathrm{J} / \mathrm{mol}$ and $\mathrm{T}$ is in $\mathrm{K}$.

Reactions (5) and (6) can be combined to obtain the standard Gibbs energy change of reaction (7) at $700{ }^{\circ} \mathrm{C}$.

$$
3 \mathrm{TiO}_{2(\mathrm{~s})}+3 \mathrm{Al}_{(\mathrm{l})}+6 \mathrm{Mg}_{(\mathrm{l})}=6 \mathrm{MgO}_{(\mathrm{s})}+3 \mathrm{TiAl}_{(\mathrm{s})}
$$

$\Delta \mathrm{G}^{\circ}{ }_{7}=\Delta \mathrm{G}^{\circ}{ }_{5}+2 \Delta \mathrm{G}^{\circ}{ }_{6}$. At $700{ }^{\circ} \mathrm{C}, \Delta \mathrm{G}^{\circ}{ }_{7}=-889,126 \mathrm{~J} / \mathrm{mol}$, hence, reaction (7) is shifted to the right to form $\mathrm{MgO}$ and TiAl.

\section{Flux Additions}

Typical salt fluxes are chloride $\mathrm{KCl}, \mathrm{NaCl}$ and $\mathrm{MgCl}_{2}$ and fluoride $\mathrm{CaF}_{2} \cdot \mathrm{MgCl}_{2}$ can be used in $\mathrm{Mg}$ alloys containing $\mathrm{Al}, \mathrm{Zn}$ and $\mathrm{Mn}$ alloying elements such as AZ91D, AM60, AM50 and AZ31 representing the majority of commercial Mg alloys. Flux entrapment, release of corrosive gas and melt losses are the major causes for the shift from flux to gas protective atmospheres [49].

\section{Alternatives to $\mathrm{SF}_{6}$ for $\mathrm{Mg}$ Melt Protection}

Fruehling, investigated protective atmospheres for molten magnesium [50]. Mirak et al. [16] summarised the significant findings on protective gases in stagnant melts held isothermally under a mixture of a protective gas (e.g., $\mathrm{SF}_{6}, \mathrm{SO}_{2}$ or 1,1,1,2-tetrafluoroethane (HFC-134a)) and a carrier gas (e.g., dry air or $\mathrm{N}_{2}$ ), based on characterisation of the reaction layer formed on the melt surface by the use of various techniques, including SEM, TEM, X-ray diffraction (XRD), X-ray photoelectron spectroscopy (XPS) and thermogravimetric analysis (TGA) and assessment of the corresponding oxidation behaviour. $\mathrm{Mg}$ melt protection in the context of the nature, origin and control of inclusions with regard to reactions with air, fluxes and protective gases during melt treatment, casting and alloying was later reviewed by Lun et al. [49].

Melt protection alternatives to both flux-based and $\mathrm{SF}_{6}$, consisting of active gases: fluorine-based blended gas (HFC-134a), fluorinated ketones (FK) and dilute $\mathrm{SO}_{2}(1.5 \%)$ mixed with a carrier gas, generally $\mathrm{N}_{2}, \mathrm{CO}_{2}$ or dry air, are commercially available [20,25,26]. The work of Ha and Kim [18] showed that hydrofluorocarbon $\mathrm{CF}_{3} \mathrm{CH}_{2} \mathrm{~F}$ (HFC-134a) possessed better protection properties than do $\mathrm{SF}_{6}$ and $\mathrm{SO}_{2}$, using air as a carrier gas. However, since HF can form in a mixture of HFC-134a/air and 
is highly corrosive, it was recommended the use of $\mathrm{N}_{2}$ or $\mathrm{CO}_{2}$ carrier gases instead of air. The reaction products between $\mathrm{Mg}$ melt and $\mathrm{SF}_{6}, \mathrm{HFC}-134 \mathrm{a}$ and $\mathrm{FK}$ are $\mathrm{MgO}$ and $\mathrm{MgF}_{2}$. Mg melt can react with $\mathrm{SO}_{2}$ to form $\mathrm{MgSO}_{4}, \mathrm{MgO}$ or $\mathrm{MgS}$ [49].

On the other hand, several alternative melt protection technologies that are not currently commercialized or readily available have been developed $[20,25,26]$. Those alternative techniques generate solid $\mathrm{CO}_{2}$, a small amount of $\mathrm{BF}_{3}$ gas and $\mathrm{SO}_{2} \mathrm{~F}_{2}$ gas for $\mathrm{Mg}$ melt protection. The use of solid $\mathrm{CO}_{2}$ can generate toxic $\mathrm{CO}$ [51]. $\mathrm{BF}_{3}$ is not a GHG, however, is highly toxic, expensive and require the use of special storage conditions [49]. It should be noted that nowadays the use of $\mathrm{SO}_{2}$ gas for $\mathrm{Mg}$ melt protection might require a $\mathrm{SO}_{2}$ scrubber system (i.e., flue gas desulfurization (FGD) technology to comply with the environmental legislation) as well as additional costs associated with corrosion of equipment handling dilute $\mathrm{SO}_{2}$. On the other hand, the Global Warming Potential (100 years) and atmospheric lifetime (years) values are 23,900, $3200\left(\mathrm{SF}_{6}\right)$; 1300, 14.6 (HFC-134a); 1, 0.014 (Novec $^{\mathrm{TM}}$ 612) and $\sim 1,-\left(\mathrm{SO}_{2} \mathrm{~F}_{2}\right)$ compared with the value of 1, 100-150 for $\mathrm{CO}_{2}$, respectively [25]. As concerns about global climate change grow, search for alternatives exist to reduce GHG emissions including HFCs.

Aarstad [9] tested a mixture of $1 \% \mathrm{SF}_{6}$ in air, $\mathrm{N}_{2}$, Ar and $\mathrm{CO}_{2}$ and $1 \% \mathrm{SO}_{2}$ in air, $\mathrm{N}_{2}$ and $\mathrm{CO}_{2}$ to determine whether a protective effect was also achieved with other carried gases than air. It was found that when using inert gases $\mathrm{N}_{2}$ and $\mathrm{Ar}$ as carrier gases, no protective film was formed on the surface of the $\mathrm{Mg}$ melt. Furthermore, $\mathrm{SF}_{6}$ in $\mathrm{CO}_{2}$ was not a successful combination, conversely when air was added to a mixture of $\mathrm{SF}_{6}$ and $\mathrm{CO}_{2}$, a protective film was formed on the melt surface. This is because air is necessary for the development of a protective film on the surface of the $\mathrm{Mg}$ melt [9]. In a parallel effort, the authors determined the solubility of fluorine in molten $\mathrm{Mg}$ in the range between $700{ }^{\circ} \mathrm{C}$ and $950{ }^{\circ} \mathrm{C}$ [52] and found that it did not appear to be sufficient for direct dissolution of fluorine into the melt to be an alternative to $\mathrm{SF}_{6}$.

Small amounts of spinel phase can form on the surface oxide layer of molten AZ91 alloy after exposure to air [53] and two plausible mechanisms for its formation were suggested by the authors. The first mechanism [53] was based on a kinetic study of the surface oxidation of liquid $\mathrm{Al}-3 \% \mathrm{Mg}$ and $\mathrm{Al}-3 \% \mathrm{Mg}-3 \% \mathrm{Si}$ alloys by Salas et al. [54], who proposed that oxidation of $\mathrm{Mg}$ to $\mathrm{MgO}$ reaction (8), can directly expose $\mathrm{MgO}$ to subsurface melt regions enriched in $\mathrm{Al}$, depleted in $\mathrm{Mg}$ compared to the bulk of the melt. This coupled with the exothermic reaction (8) at a rate sufficient to cause local superheating of the melt may result in the formation of $\mathrm{Al}_{2} \mathrm{O}_{3}$ and $\mathrm{MgAl}_{2} \mathrm{O}_{4}$ through the endothermic reactions (6) (shifted to the left) and (9), respectively. Spinel would hence form at the alloy/MgO interface.

$$
\mathrm{Mg}_{(\mathrm{g})}+1 / 2 \mathrm{O}_{2(\mathrm{~g})}=\mathrm{MgO}_{(\mathrm{s})}
$$

$\Delta \mathrm{G}^{\circ} \mathrm{MgO}=-612,955+128.08 \mathrm{~T}[14,15,19]$

$$
4 \mathrm{MgO}_{(\mathrm{s})}+2 \mathrm{Al}_{(\mathrm{l})}=\mathrm{MgAl}_{2} \mathrm{O}_{4(\mathrm{~s})}+3 \mathrm{Mg}_{(\mathrm{l})}
$$

$\Delta \mathrm{G}^{\circ}{ }_{7}=110,210-28.41 \mathrm{~T}$ [48], where $\Delta \mathrm{G}^{\circ}$ is in $\mathrm{J} / \mathrm{mol}$ and $\mathrm{T}$ is in $\mathrm{K}$.

The second mechanism [53] was based on an immediate oxidation to $\mathrm{Al}_{2} \mathrm{O}_{3}$ and $\mathrm{MgO}$ and their solid state reaction [55-57] (reaction (10)) to form spinel through-thickness.

$$
\mathrm{MgO}_{(\mathrm{s})}+\mathrm{Al}_{2} \mathrm{O}_{3(\mathrm{~s})}=\mathrm{MgAl}_{2} \mathrm{O}_{4(\mathrm{~s})}
$$

at $800{ }^{\circ} \mathrm{C}, \Delta \mathrm{G}^{\circ}{ }_{\mathrm{MgAl} 2 \mathrm{O} 4}=-46,700 \mathrm{~J} / \mathrm{mol}$ [58].

Recent work is also indicating that there may be approaches to $\mathrm{Mg}$ alloy process routes without protective gas other than $\mathrm{SF}_{6}$ gas. $\mathrm{Mg}$ alloy melting can be carried out lowering the oxygen content inside the enclosed area [3] to prevent catastrophic oxidation, ignition and burning of the melt [35,59]. Kim et al. [2] demonstrated successfully the development of AZ31 Mg alloy wrought process route without protective gas, instead, by the addition of $0.42 \mathrm{wt} . \% \mathrm{CaO}$ to AZ31 alloy melt being protected 
by $\mathrm{N}_{2}$ gas in the temperature range from $640{ }^{\circ} \mathrm{C}$ to $660^{\circ} \mathrm{C}$. This reveals alternative approaches to $\mathrm{Mg}$ melting and demonstrates the need for further research into the entire topic.

Elimination [60] or reduction [61] of protective $\mathrm{SF}_{6}$ gas has been achieved in the development of innovative processes such as semi-solid injection moulding. However, just as important to process considerations are the addition of inoculants such as $\mathrm{MgO}$ [62] and $\mathrm{Al}_{4} \mathrm{C}_{3}[63,64]$ to produce a grain-refined microstructure. AZ91D chips were mixed with carbon black using a semi-solid injection moulding technique at $630^{\circ} \mathrm{C}$, the in situ reaction between aluminium and carbon occurred to form $\mathrm{Al}_{4} \mathrm{C}_{3}$ particles [64]. The authors found an optimal carbon black addition of $0.23 \mathrm{wt} \%$ to produce a grain-refined microstructure giving improved properties. Carbon's reaction kinetics are critical to the conversion efficiency, which in turn can affect the effectiveness of corrosion resistance.

Pure $\mathrm{CO}_{2}$ [50] and mixtures up to 20 vol.\% air $/ \mathrm{CO}_{2}$ can protect molten magnesium $[9,65,66]$. Equally important, however, are carbon's reaction kinetics. A thermodynamic analysis by Aarstad [9] predicted that traces of $\mathrm{CO}\left(1.0 \times 10^{-7}\right.$ moles $)$ and $\mathrm{O}_{2}\left(5.1 \times 10^{-8}\right.$ moles $)$ were the decomposition products of 1 mole of $\mathrm{CO}_{2}$ at $700{ }^{\circ} \mathrm{C}$ and 1 bar pressure, and that $\mathrm{MgO}$ and $\mathrm{C}$ were the reaction products between $\mathrm{CO}_{2}$ and molten $\mathrm{Mg}$. In parallel, Shih et al. $[67,68]$ reported the possible reactions that can occur between $\mathrm{Mg}$ and, $\mathrm{O}_{2}, \mathrm{CO}_{2}$ and $\mathrm{CO}$ (reactions (8), (11)-(13)). A diagram of the standard Gibbs energy change versus temperature for the reactions (11)-(13) is given in Reference [67], from which it can be seen that, reactions (9)-(11) can proceed spontaniously until about $3725^{\circ} \mathrm{C}, 2475{ }^{\circ} \mathrm{C}$ and $1975^{\circ} \mathrm{C}$, respectively. In particular, at $720^{\circ} \mathrm{C}, \Delta \mathrm{G}^{\circ} 12=-592,700 \mathrm{~J} / \mathrm{mol}$ [66].

$$
\begin{gathered}
\mathrm{Mg}_{(\mathrm{g})}+\mathrm{CO}_{2(\mathrm{~g})}=\mathrm{MgO}_{(\mathrm{s})}+\mathrm{CO}_{(\mathrm{g})} \\
\mathrm{Mg}_{(\mathrm{l}),(\mathrm{g})}+1 / 2 \mathrm{CO}_{2(\mathrm{~g})}=\mathrm{MgO}_{(\mathrm{s})}+1 / 2 \mathrm{C}_{(\mathrm{s})} \\
\mathrm{Mg}_{(\mathrm{l}),(\mathrm{g})}+\mathrm{CO}_{(\mathrm{g})}=\mathrm{MgO}_{(\mathrm{s})}+\mathrm{C}_{(\mathrm{s})}
\end{gathered}
$$

Thermo-oxidative experiments of pure $\mathrm{Mg}$ in the liquid state $[65,66]$ have been performed by isothermal TGA in pure $\mathrm{CO}_{2}$ and mixtures up to $20 \mathrm{vol}$ \% air $/ \mathrm{CO}_{2}$ to monitor the surface oxidation kinetics at high temperatures $\left(670{ }^{\circ} \mathrm{C}, 720^{\circ} \mathrm{C}\right.$ and $\left.770{ }^{\circ} \mathrm{C}\right)$ and to relate those to their morphological and structural characteristics at different oxidation stages (2,3 and $7 \mathrm{~min})$ as determined by SEM. The TGA and SEM results by Emami and Sohn $[65,66]$ indicated that the surface had a double-layer structure. The external layer consisted of non-protective $\mathrm{MgO}$, whereas the internal layer was dense and protective, and composed of a mixture of $\mathrm{MgO} / \mathrm{C}$.

Note the solubility of $\mathrm{C}$ in liquid $\mathrm{Mg}$. According to the $\mathrm{Mg}-\mathrm{C}$ equilibrium phase diagram which was proposed in Reference [69], the value of the solubility of C in $\mathrm{Mg}$ is approximately 10 at ppm (5 wt. ppm) at $700{ }^{\circ} \mathrm{C}$. The solubility of $\mathrm{C}$ in liquid $\mathrm{Mg}$ increases with increasing temperature up to $1093.6^{\circ} \mathrm{C}$ at 1 bar pressure. All of these results suggest that both melt protection and grain refinement should be considered in developing practical applications for using $\mathrm{CO}_{2}$ in $\mathrm{Mg}$ - $\mathrm{Al}$ based alloys.

\section{Conclusions}

This paper has examined the topic of $\mathrm{Mg}$ melt protection. Among alternative cover gas technologies for $\mathrm{Mg}$ melt protection other than $\mathrm{SF}_{6}$ : Commercially available technologies containing-HFC-134a, fluorinated ketone and dilute $\mathrm{SO}_{2}$ - and developed technologies containing solid $\mathrm{CO}_{2}, \mathrm{BF}_{3}$ and $\mathrm{SO}_{2} \mathrm{~F}_{2}$, can potentially produce toxic and/or corrosive by-products. Additions of alkaline earth metal oxides to $\mathrm{Mg}$ and its alloys have developed a strong comparative advantage in the field of $\mathrm{Mg}$ melt protection.

The near-future challenges and opportunities for $\mathrm{Mg}$-Al based alloys include, optimising and using $\mathrm{CO}_{2}$ gas as feedstock for both melt protection and grain refinement, and $\mathrm{TiO}_{2}$ additions for melt protection, in order to design and manufacture sustainable $\mathrm{Mg}$ alloys for resource efficiency, recycling and minimising waste. 
Acknowledgments: The financial support of Engineering and Physical Sciences Research Council (EPSRC) is gratefully acknowledged.

Author Contributions: All the authors contributed equally to this work.

Conflicts of Interest: The authors declare no conflict of interest.

\section{References and Notes}

1. Emley, E.F. Principles of Magnesium Technology; Pergamon Press: Oxford, UK, 1966.

2. Kim, S.K.; Lee, J.K.; Yoon, Y.O.; Jo, H.H. Development of AZ31 Mg alloy wrought process route without protective gas. J. Mater. Process. Technol. 2007, 187-188, 757-760. [CrossRef]

3. Foerster, G. HiLoN: A new approach to magnesium die casting. Adv. Mater. Process. 1998, 154, 79.

4. Kim, S.K.; Hoseo, J. Magnesium-Based Alloy with Superior Fluidity and Hot-Tearing Resistance and Manufacturing Method Thereof. US Patent 20110236249 A1, 29 September 2011.

5. Dervos, C.T.; Vassiliou, P. Sulfur hexafluoride $\left(\mathrm{SF}_{6}\right)$ : Global environmental effects and toxic byproduct formation. J. Air Waste Manag. Assoc. 2000, 50, 137-141. [CrossRef] [PubMed]

6. Aghion, E.; Gurion, B.; Bartos, S.C. Comparative Review of Primary Magnesium Production Technologies as Related to Global climate Change. In Proceedings of the 65th Annual World Magnesium Conference, Warsaw, Poland, 18-20 May 2008; Available online: http://www.citysat.com.pl/ \{\}omen/2008_World_Mg_ Conference_Papers (accessed on 17 January 2016).

7. Cashion, S.P.; Ricketts, N.J.; Hayes, P.C. Characterisation of protective surface films formed on molten magnesium protected by air $/ \mathrm{SF}_{6}$ atmospheres. J. Light Metals 2002, 2, 37-42. [CrossRef]

8. Cashion, S.P.; Ricketts, N.J.; Hayes, P.C. The mechanism of protection of molten magnesium by cover gas mixtures containing sulphur hexafluoride. J. Light Metals 2002, 2, 43-47. [CrossRef]

9. Aarstad, K. Protective Films on Molten Magnesium. Ph.D. Thesis, Norwegian University of Science and Technology, Norway, May 2004. Available online: http://www.diva-portal.org/smash/get/diva2:126206/ FULLTEXT01.pdf (accessed on 19 March 2016).

10. Aarstad, K.; Tranell, G.; Engh, T.A. Various Techniques to Study the Surface of Magnesium Protected by SF . $_{6}$ Magnes. Technol. 2003, 5-10. Available online: http://www.academia.edu/24051179/Various_techniques_ to_study_the_surface_of_magnesium_protected_by_SF6 (accessed on 26 May 2016).

11. Xiong, S.M.; Liu, X.L. Microstructure, composition, and depth analysis of surface films formed on molten AZ91D alloy under protection of $\mathrm{SF}_{6}$ mixtures. Metall. Mater. Trans. A: Phys. Metall. Mater. Sci. 2007, 38A, 428-434. [CrossRef]

12. Wang, X.F.; Xiong, S.M. Oxidation behavior of molten magnesium in atmospheres containing $\mathrm{SO}_{2}$. Corros. Sci. 2011, 53, 4050-4057. [CrossRef]

13. Pettersen, G.; Øvrelid, E.; Tranell, G.; Fenstad, J.; Gjestland, H. Characterisation of the surface films formed on molten magnesium in different protective atmospheres. Mater. Sci. Eng. A 2002, 332, 285-294. [CrossRef]

14. Liu, J.R.; Chen, H.K.; Zhao, L.; Huang, W.D. Oxidation behaviour of molten magnesium and AZ91D magnesium alloy in 1,1,1,2-tetrafluoroethane/air atmospheres. Corros. Sci. 2009, 51, 129-134. [CrossRef]

15. Chen, H.; Liu, J.; Huang, W. The protective surface film formed on molten ZK60 magnesium alloy in 1,1,1,2-tetrafluoroethane/air atmospheres. Corros. Sci. 2010, 52, 3639-3645. [CrossRef]

16. Mirak, A.; Davidson, C.J.; Taylor, J.A. Characterisation of fresh surface oxidation films formed on pure molten magnesium in different atmospheres. Corros. Sci. 2010, 52, 1992-2000. [CrossRef]

17. Chen, H. Effect of melt temperature on the oxidation behaviour of AZ91D magnesium alloy in 1,1,1,2-tetrafluoroethane/air atmospheres. Mater. Charact. 2010, 61, 894-898. [CrossRef]

18. Ha, W.; Kim, Y.J. Effects of cover gases on melt protection of Mg alloys. J. Alloy. Compd. 2006, 422, $208-213$. [CrossRef]

19. Zhao, L.; Liu, J.R.; Chen, H.K.; Huang, W.D. The characterization of surface films formed on molten magnesium and AZ91D alloy in air/1,1,1,2-tetrafluoroethane atmospheres. J. Alloy. Compd. 2009, 480, 711-716. [CrossRef]

20. Milbrath, D.S. Development of $3 \mathrm{M}^{\mathrm{TM}}$ Novec $^{\mathrm{TM}} 612$ Magnesium Protection Fluid as a Substitute for $\mathrm{SF}_{6}$ over Molten Magnesium. In Proceedings of the 2nd International Conference on $\mathrm{SF}_{6}$ and the Environment, San Diego, CA, USA, 22 November 2002; Available online: https:/ /www.epa.gov/sites/production/files / 2016-02/documents/conf02_milbrath_paper.pdf (accessed on 20 May 2016). 
21. Emami, S.; Sohn, H.Y.; Kim, H.G. Formation and evaluation of protective layer over magnesium melt under $\mathrm{SF}_{6} /$ Air atmospheres. Metall. Mater. Trans. B 2014, 45, 1370-1379. [CrossRef]

22. Regulation (EU) No 517/2014 of the European Parliament and of the Council of 16 April 2014 of fluorinated greenhouse gases and repealing.

23. Wiese, B.; Mendis, C.L.; Ovri, H.; Reichel, H.-P.; Lorenz, U.; Kainer, K.U.; Hort, N. Role of CaO and Cover Gases on Protecting the Cast Surface of Mg. In Proceedings of the 10th International Conference on Magnesium Alloys and Their Applications, Jeju, Korea, 11-16 October 2015; pp. 814-819.

24. Dishon, A. Financial Benefits from $\mathrm{SF}_{6}$ Emission Reductions. In Proceedings of the 65th Annual World Magnesium Conference, Warsaw, Poland, 18-20 May 2008; Available online: http:/ /www.citysat.com.pl/ $\sim\{\}$ omen/2008_World_Mg_Conference_Papers (accessed on 17 January 2016).

25. Alternatives to $\mathrm{SF}_{6}$ for Magnesium Melt Protection. Available online: https://www.epa.gov/sites/ production/files/2016-02/documents/magbrochure_english.pdf (accessed on 20 May 2016).

26. Hillis, J.E. The International Program to Identify Alternatives to $\mathrm{SF}_{6}$ for Magnesium Melt Protection. In Proceedings of the International Conference on $\mathrm{SF}_{6}$ and the Environment: Emission Reduction Strategies, San Diego, CA, USA, 21-22 November 2002; Available online: https://www.epa.gov/sites/production/ files/2016-02/documents/conf02_hillis_paper.pdf (accessed on 20 May 2016).

27. Czerwinski, F. The reactive element effect on high-temperature oxidation of magnesium. Int. Mater. Rev. 2015, 60, 264-296. [CrossRef]

28. Pfeil, L.B. Improvements relating to hear-resisting alloys containing chromium. UK Patent No. 574088, 20 December 1945.

29. Beranger, G.; Armanet, F.; Lambertin, M. Active Elements in Oxidation and Their Properties. In The Role of Active Elements in the Oxidation Behaviour of High Temperature Metals and Alloys, Proceedings of the European Colloquium Organised by: Commission of the European Communities, Directorate General: Science, Research and Development, Petten, The Netherlands, 12-13 December 1988; Lang, E., Ed.; Elsevier Applied Science: London, UK; New York, NY, USA, 1988; pp. 33-51.

30. Czerwinski, F. Oxidation characteristics of magnesium alloys. JOM 2012, 64, 1477-1483. [CrossRef]

31. Aydin, D.S.; Bayindir, Z.; Hoseini, M.; Pekguleryuz, M.O. The high temperature oxidation and ignition behaviour of Mg-Nd alloys part I: The oxidation of dilute alloys. J. Alloy. Compd. 2013, 569, 35-44. [CrossRef]

32. Pint, B.A. Experimental observations in support of the dynamic-segregation theory to explain the reactive-element effect. Oxid. Metals 1996, 45, 1-37. [CrossRef]

33. Ellingham, H.J.T. Reducibility of oxides and sulfides in metallurgical processes. J. Soc. Chem. Ind. (Lond.) 1944, 63, 125-133.

34. Howard, S.M. Ellingham Diagrams, Internet Resource for MET 320-Metallurgical Thermodynamics, South Dakota School of Mines and Technology, Rapid City, SD, USA. Available online: http:/ / showard.sdsmt.edu/ MET320/Handouts/EllinghamDiagrams/Ellingham_v22_Macro.pdf (accessed on 12 May 2016).

35. Sakamoto, M.; Akiyama, S.; Ogi, K. Suppression of ignition and burning of molten Mg alloys by Ca bearing stable film. J. Mater. Sci. Lett. 1997, 16, 1048-1050. [CrossRef]

36. Nayeb-Hashemi, A.A.; Clark, J.B. The Ca-Mg (Calcium-Magnesium) system. Bull. Alloy Phase Diagr. 1987, 8, 58-65. [CrossRef]

37. Wiese, B.; Mendis, C.L.; Tolnai, D.; Stark, A.; Schell, N.; Reichel, H.-P.; Brückner, R.; Kainer, K.U.; Hort, N. CaO dissolution during melting and solidification of a Mg-10 wt.\% $\mathrm{CaO}$ alloy detected with in situ synchrotron radiation diffraction. J. Alloy. Compd. 2015, 618, 64-66. [CrossRef]

38. Wiese, B.; Tolnai, D.; Mendis, C.L.; Eckerlebe, H.; Hort, N. In situ Diffraction of the Melting and the Solidification of Magnesium Alloys Containing CaO. Available online: http://photon-science.desy.de/ annual_report/files/2013/20132901.pdf (accessed on 14 January 2016).

39. Pekguleryuz, M.O. Alloying behaviour of magnesium and alloy design. In Fundamentals of Magnesium Alloy Metallurgy; Pekguleryuz, M.O., Kainer, K.U., Kaya, A.A., Eds.; Woodhead Publishing Ltd.: Oxford, UK; Cambridge, PA, USA; New Delhi, India, 2003; p. 169.

40. Friedrich, H.E.; Mordike, B.L. Magnesium Technology: Metallurgy, Design Data, Applications; Springer-Verlag: Berlin, Germany, 2006; p. 119.

41. Czerwinski, F.; Zielinska-Lipiec, A. The microstructure evolution during semisolid molding of a creep-resistant Mg-5Al-2Sr alloy. Acta Mater. 2005, 53, 3433-3444. [CrossRef] 
42. Balart, M.J.; Fan, Z. Surface oxidation of molten AZ31, AM60B and AJ62 magnesium alloys in air. Int. J. Cast Metals Res. 2014, 27, 301-311. [CrossRef]

43. Nayeb-Hashemi, A.A.; Clark, J.B. The Mg-Sr (Magnesium-Strontium) system. Bull. Alloy Phase Diagr. 1986, 7, 149-156. [CrossRef]

44. Balart, M.J.; Fan, Z. Surface oxidation of molten AZ91D magnesium alloy in air. Int. J. Cast Metals Res. 2014, 27, 167-175. [CrossRef]

45. Kang, H.; Kang, S.; Park, S.; Bae, D. An Interstitial Magnesium Alloy Containing Oxygen Atoms. In Proceedings of the 10th International Conference on Magnesium Alloys and Their Applications, Jeju, Korea, 11-16 October 2015.

46. Payyapilly, J.J. Formation and Growth Mechanisms of a High Temperature Interfacial Layer Between $\mathrm{Al}$ and $\mathrm{TiO}_{2}$. Ph.D. Thesis, Virginia Polytechnic Institute and State University, Blacksburg, VA, USA, 19 November 2008. pp. 77, 79. Available online: https://vtechworks.lib.vt.edu/bitstream/handle/10919/29733/Jairaj.pdf (accessed on 19 March 2016).

47. Umakoshi, Y.; Yamaguchi, M.; Sakagami, T.; Yamane, T. Oxidation resistance of intermetallic compounds $\mathrm{Al}_{3}$ Ti and TiAl. J. Mater. Sci. 1989, 24, 1599-1603. [CrossRef]

48. Huang, Z.; Sirong, Y. Microstructure characterization on the formation of in situ $\mathrm{Mg}_{2} \mathrm{Si}$ and $\mathrm{MgO}$ reinforcements in AZ91D/Flyash composites. J. Alloy. Compd. 2011, 509, 311-315. [CrossRef]

49. Lun Sin, S.; Elsayed, A.; Ravindran, C. Inclusions in magnesium and its alloys: A review. Int. Mater. Rev. 2013, 58, 419-436. [CrossRef]

50. Fruehling, J.W. Protective Atmospheres for Molten Magnesium. Ph.D. Thesis, The University of Michigan, Ann Arbor, MI, USA, 1970.

51. Norbert, H.; Wiese, B.; Dieringa, H.; Ulrich Kainer, K. Magnesium melt protection. Mater. Sci. Forum 2015, $828-829,78-81$.

52. Aarstad, K.; Syvertsen, M.; Engh, T.A. Solubility of Fluorine in Molten Magnesium. Magnes. Technol. 2002. [CrossRef]

53. Shih, T.S.; Liu, J.B.; Wei, P.S. Oxide films on magnesium and magnesium alloys. Mater. Chem. Phys. 2007, 104, 497-504. [CrossRef]

54. Salas, O.; Ni, H.; Jayaram, V.; Vlach, K.C.; Levi, C.G.; Mehrabian, R. Nucleation and growth of $\mathrm{Al}_{2} \mathrm{O}_{3} / \mathrm{metal}$ composites by oxidation of aluminium alloys. J. Mater. Res. 1991, 6, 1964-1981. [CrossRef]

55. Wagner, C. Mechanism of counterdiffusion through reaction in the solid state. Z. Anorg. Allg. Chem. 1938, 236, 320-338. [CrossRef]

56. Carter, R.E. Mechanism of solid state reaction between $\mathrm{MgO}$ and $\mathrm{Al}_{2} \mathrm{O}_{3}$ and $\mathrm{MgO}$ and $\mathrm{Fe}_{2} \mathrm{O}_{3}$. J. Am. Ceram. Soc. 1961, 44, 116-120. [CrossRef]

57. Hesse, D.; Senz, S. Interfacial reaction mechanisms and the structure of moving heterophase boundaries during pyrochlore- and spinel-forming solid state reactions. Z. Metallkunde 2004, 95, 252-257. [CrossRef]

58. Gaskell, D.R. Reaction equilibria in systems containing components in condensed solution. In Introduction to the Thermodynamics of Materials, 5th ed.; Taylor \& Francis Group: New York, NY, USA; London, UK, 2012; p. 430. Available online: https://books.google.co.uk/books?id=3xfcBQAAQBAJ\&pg=PA430\&lpg=PA430\& $\mathrm{dq}=$ free+energy+MgAl2O4\&source=bl\&ots=wGdalbSfqk\&sig=bpZG2u3G_ElsbBet6uJOnfBP-oY\&hl=en\& sa=X\&ved=0ahUKEwibgLqn5L3MAhULKx4KHWUKA-kQ6AEIKzAE\#v=onepage\&q=free $\% 20 \mathrm{energy} \%$ 20MgAl2O4\&f=false (accessed on 5 May 2016).

59. Jafari, H.; Idris, M.H.; Ourdjini, A. High temperature oxidation of AZ91D magnesium alloy granule during in situ melting. Corros. Sci. 2011, 53, 655-663. [CrossRef]

60. Czerwinski, F. The oxidation behaviour of an AZ91D magnesium alloy at high temperatures. Acta Mater. 2002, 50, 2639-2654. [CrossRef]

61. Fan, Z.; Ji, S.; Fang, X.; Liu, G.; Patel, J.B.; Das, A. Development of Rheo-diecasting (RDC) Process for Production of High Integrity Components. In Proceedings of the Shape Casting: 2nd International Symposium, Orlando, FL, USA, 1 May 2007; Crepeau, P.N., Tiryakioglu, M., Campbell, J., Eds.;

62. Wang, Y.; Fan, Z.; Thompson, G. Characterization of magnesium oxide and its interface with alpha Mg in Mg-Al based alloys. Philos. Mag. Lett. 2011, 91, 516-529. [CrossRef]

63. Lee, Y.C.; Dahle, A.K.; StJohn, D.H. The role of solute in grain refinement of magnesium. Metall. Mater. Trans. A 2013, 31A, 2895-2906. [CrossRef] 
64. Fukuta, T.; Obunai, K.; Ozaki, K.; Shibata, K. Improvement of mechanical properties of injection molded AZ91D alloy by mixing carbon black as a grain refinement additive. In Proceedings of the 10th International Conference on Magnesium Alloys and Their Applications, Jeju, Korea, 11-16 October 2015; pp. 551-557.

65. Emami, S. Formation and Evaluation of Protective Layer Over Magnesium Melt Under Various Gaseous Atmospheres. Ph.D. Thesis, The University of Utah, Salt Lake City, UT, USA, December 2013. Available online: http://content.lib.utah.edu/utils/getfile/collection/etd3/id/2640/filename/2637.pdf (accessed on 19 March 2016).

66. Emami, S.; Sohn, H.Y. Formation and evaluation of protective layer over magnesium melt under $\mathrm{CO}_{2} /$ air mixtures. Metall. Mater. Trans. B 2015, 46, 226-234. [CrossRef]

67. Shih, T.S.; Chung, C.B.; Chong, K.Z. Combustion of AZ61A under different gases. Mater. Chem. Phys. 2002, 74, 66-73. [CrossRef]

68. Shih, T.S.; Wang, J.H.; Chong, K.Z. Combustion of magnesium alloys in air. Mater. Chem. Phys. 2004, 85, 302-309. [CrossRef]

69. Chen, H.L.; Schmid-Fetzer, R. The Mg-C phase equilibria and their thermodynamic basis. Int. J. Mater. Res. 2012, 103, 1294-1301. [CrossRef]

(C) 2016 by the authors; licensee MDPI, Basel, Switzerland. This article is an open access article distributed under the terms and conditions of the Creative Commons Attribution (CC-BY) license (http://creativecommons.org/licenses/by/4.0/). 